\section{The appearance of angiolipomatosis after using laptop computer on the thighs: a relationship?}

\author{
Marie Caucanas,' Gebhard Müller, ${ }^{2}$ \\ Olivier Vanhooteghem ${ }^{1}$ \\ 'Department of Dermatology, \\ Clinique Sainte Elisabeth, Namur; \\ ${ }^{2}$ Institute of Pathology and Genetics, \\ Gosselies, Belgium
}

\begin{abstract}
A 56-year-old patient developed angiolipomatosis of the anterior part of the thighs after repeated laptop contact localisation. Histological findings exhibit an unusual inflammatory infiltrate. We postulate that the computer could favour lipoma development by a physiopathological mechanism that remains to be clarified.
\end{abstract}

\section{Case Report}

A 56-year-old woman gradually developed subcutaneous nodules on the thighs over the course of two years. The patient has no medical or familial history and does not take any medication. She is a speech specialist and admits working several times a week for a couple of hours with her laptop over her thighs. Clinical examination shows the existence of approximately ten nodules strictly localised on the anterior part of the thighs (Figure 1), suggesting clinical lipomatosis.

An excisional biopsy of a nodule shows angiolipomatosis with mild to moderate inflammatory infiltrate with CD68-positive macrophages and T lymphocytes (Figure 2).

The patient stopped putting her laptop on her thighs for one year and observed stabilisation of nodule count number, but no regression was noted.

\section{Discussion}

This is the first description of a secondary lipomatosis of the thighs with the regular use of a laptop computer on this specific location. Histological examination shows angiolipomatosis associated with an inflammatory infiltrate of histiocytes and T lymphocytes. According to the imputability criteria, ${ }^{1}$ it is highly plausible that the use of the laptop in contact with the thighs caused the development of underlying lipomas, as the rapid onset of nodules was observed with the use of the laptop, and the stabilisation of the lesions was observed after the laptop was no longer used at that location. This suggests a symmetric semiology and parallel evolution, and the absence of any other explanation for the condition after full examination supports this conclusion despite the absence of any reliable specific complementary examination proving the link of causality to the histological findings. We think that the laptop is responsible for the development of the lipomas. The inflammation found upon histological examination could have been provoked by the computer through an unknown mechanism and could involve the influence of the heat emitted by the battery and/or the electromagnetic waves emanating from the device. After changing her working habits, the number of lipomas stabilised but did not regress.

The use of new technologies, which continue to development and become more accessible, were recently associated with unsuspected pathologies. The semicircular lipoatrophy of the thighs, described by a series of hundreds of patients in companies equipped with the most recent models of fixed computers, is secondary to electromagnetic lipolysis, which is facilitated by local circumstances such as the conductivity of the material of the desks, the ambient humidity and the inappro-

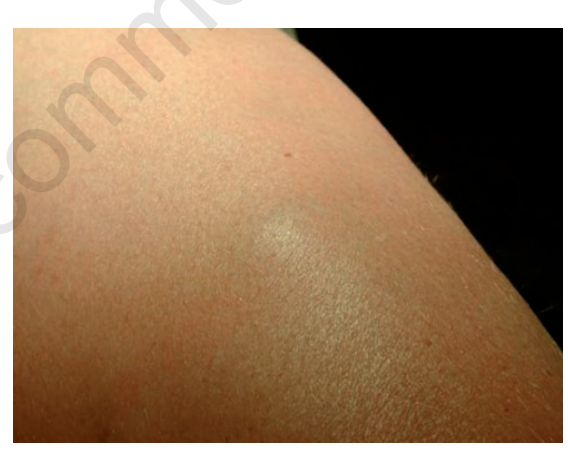

Figure 1. Lipomatosis of the anterior part of the thigh.

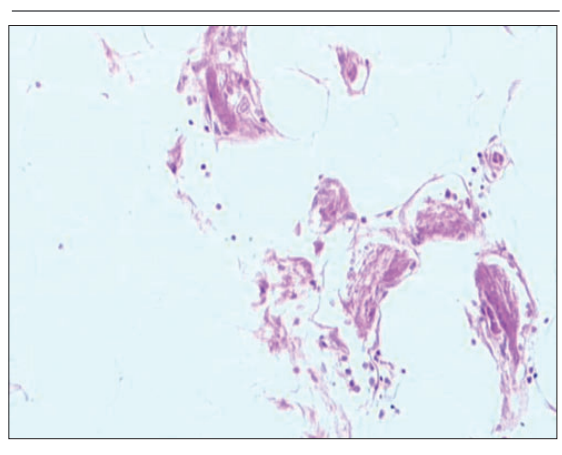

Figure 2. Inflammatory infiltrate associated with angiolipomatosis.
Correspondence: Olivier Vanhooteghem, Sainte Elisabeth Hospital, Dermatology Unit, Namur, Belgium.

E-mail: ovanhooteghem@hotmail.com

Key words: lipoma, angiolipomatosis, laptop computer, electromagnetic waves, thighs, nodules.

Conflict of interest: all authors certified that they have no conflicts of interest, including specific financial interests and relationships and affiliations relevant to the subject of this manuscript.

Received for publication: 6 August 2011.

Accepted for publication: 9 August 2011.

This work is licensed under a Creative Commons Attribution NonCommercial 3.0 License (CC BYNC 3.0).

(C) Copyright M. Caucanas et al., 2011

Licensee PAGEPress, Italy

Dermatology Reports 2011; 3:e22

doi:10.4081/dr.2011.e22

priate insulation of computer wiring. ${ }^{2-6}$

Five cases of erythema ab igne dermatitis developed after regular use of a laptop on the thighs have been described since 2004. ${ }^{7-14}$ As suggested by the case of our patient, the development of lipoma could be a consequence of the extensive usage of the computer with immediate contact on the body. The exact physiopathological mechanism behind this pathology remains to be clarified.

\section{References}

1. Bégaud B, Evreux JC, Jouglard J, Lagier G. Imputabilité des effets inattendus ou toxiques des médicaments. Actualisation de la méthode utilisée en France. Therapie 1985;40:111-8.

2. Flagothier C, Quatresooz P, Pierard G-E. Electrolipolysis and semicircular lipoatrophy of the thighs. Ann Dermatol Venereol 2006;133:577-80.

3. Panella H, Juanola E, de Peray JL, Artazcoz L. Semicircular lipoatrophy : a new occupational disease. Gac Sanit 2008;22:73-5.

4. Lachapelle JM, Tennstedt D. Nouvelles dermatoses de l'environnement. Progrès en dermato-allergologie. Dijon 2002. Ed. E. Collet. John Libbey Eurotext, Montrouge 2002,pp.157-65.

5. Hermans V, Hautekiet M, Haex B, Spaepen AJ, Van der Perre G. Lipoatrophia semicircularis and the relation with office work. Applied Ergonomics 1999;30:319-24.

6. Curvers B, Maes A. Lipoatrophia semicircularis: a new office disease? 900 cases reported in Belgium. www.next-up.org 
7. Bilic M, Adams BB. Erythema ab igne induced by a laptop computer. J Am Acad Dermatol 2004;50:973-4.

8. Jagtman BA. Erythema ab igne due to a laptop computer. Contact Dermatitis 2004;50:105.

9. Maalouf E, Simantov A, Rosenbaum F, Chosidow 0. Erythema ab igne as an unexpected computer side-effect. Dermatology 2006;212:392-3.
10. Mohr MR, Scott KA, Pariser RM, Hood AF. Laptop computer-induced erythema ab igne: a case report. Cutis 2007;79: 59-60.

11. Levinbook WS, Mallett J, Grant-Kels JM. Laptop computer associated erythema ab igne. Cutis 2007;80:319-20.

12. Bachmeyer C, Bensaid P, Bégon E. Laptop computer as a modern cause of erythema ab igne. J Eur Acad Dermatol Venereol 2009;23:736-7.

13. Fite C, Bouscarat F. Laptop computer-induced erythema Ab Igne. Presse Med 2009; 38:1164-5.

14. Gohar A. Comment on the letter by Bachmeyer, Bensaid and Bégon on laptop computer as a modern cause of erythema ab igne. J Eur Acad Dermatol Venereol 2009;23:1221-2. 